\title{
Power Generation and Regional Collaboration in South Asia
}

\author{
Firoz Alam ${ }^{1, *}$, Rashid Sarkar ${ }^{2, * *}$, Quamrul Alam ${ }^{3}$ \\ ${ }^{I}$ School of Aerospace, Mechanical and Manufacturing Engineering, RMIT University, Melbourne, Australia \\ ${ }^{2}$ Department of Mechanical Engineering, Bangladesh University of Engineering and Technology (BUET), Dhaka 1000, \\ Bangladesh \\ ${ }^{3}$ School of Business and Law, Central Queensland University, Melbourne, Australia \\ Corresponding Email: firoz.alamermit.edu.au; drmarsarkar@gmail.com
}

\begin{abstract}
:
Inadequate power generation and supply are considered to be the main hindrance of economic development and prosperity in South Asia. Limited indigenous energy resource of each South Asian nation is not suitable to generate sufficient power. Moreover, the availability of limited indigenous energy resources differs among South Asian nations. The power demand and power generation capacity notably vary among the countries due to seasonal variability. This paper highlights the need for a collective effort to develop mechanism for the utilisation of limited resources and enhance the cross-border power trade among South Asian nations. Bilateral and multi-lateral cooperation will allow overcoming regional power shortage and augmenting collective energy security.
\end{abstract}

Keywords: Energy, Power, Energy Security, Hydro Resource, Cross Border Power Trade

\section{Introduction}

South Asian nations- Afghanistan, Bangladesh, Bhutan, India, Maldives, Nepal, Pakistan and Sri Lanka are the home for over one-quarter of world's population $(\sim 1.7$ billion). Despite having strong cultural and linguistic bonds, the region is least connected and less traded bilaterally and multi-laterally [1-6]. The shortage of power generation, power transmission and distribution infrastructure are considered to be the main deterrent for economic prosperity of the region [7-12]. The region aspires to be fully developed nations by the middle of 21 st century. Rapid industrialization and attainment of sustainable development are vital to achieve this goal.

Currently the entire South Asian region is energy deficient [10-13]. They need to have secured energy, power generation, distribution and supply. The total installed power generation capacity in South Asia is approximately $401,706 \mathrm{MW}$. The power demand is rising by around $10 \%$ each year. Additionally, hundreds of million inhabitants have no access to grid connected power. The current installed power generation capacity in each South Asian nation is shown in Figure 1. The energy mix for power generation varies significantly in the region. The power generation in Bhutan and Nepal is propelled by hydro energy while Maldives' power generation is almost entirely based on imported fossil fuel. Coal is the primary energy for power generation in India while the natural gas is predominantly for Bangladesh.

In South Asia, grid connected power consumers face 4-8 hours power outages (load shedding) in each day due to insufficient power generation, power transmission and distribution. These outages cause significant economic losses. Table 1 shows the current, forecasted and peak power demand in South Asian nations.

Pakistan and Bangladesh face acute power shortages due to heavy reliance on domestic gas which is depleting rapidly. Nepal experiences severe power shortage during winter season. At present, five out of eight South Asian nations undertake cross border power trading from their neighbours. India imports power from Bhutan but exports power to Nepal, Bangladesh and Myanmar (Burma). Afghanistan imports nearly three-quarter of its power from Uzbekistan, Turkmenistan, Iran and Tajikistan. Pakistan has planned to import power from Central Asia by 2019. A cross-border underwater interconnection between Sri Lanka and India is currently under construction. A brief summary of current bilateral power trade is furnished in next sub-section.

\subsection{Afghanistan (net importer)}

Afghanistan's fragmented generation, transmission, and distribution, and security situation make it most difficult to provide grid connected power to consumer. Grid 


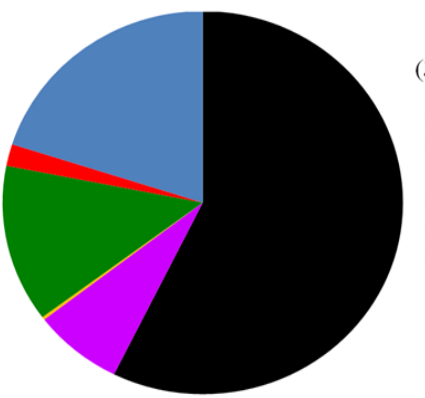

India (344,003 MW)

- Coal $(58 \%)$ - Gas $(7 \%)$

- Diesel (0)

- Hydro (13\%)

- Nuclear $(2 \%)$

= Others $(20 \%)$

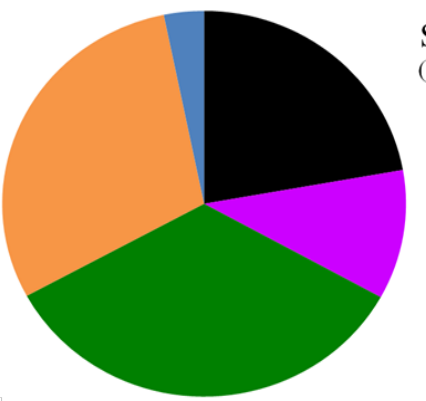

Sri Lanka (4,055 MW)

- Coal $(22 \%)$

- Gas (11\%)

- Hydro (34\%)

- Nuclear $(0 \%)$

- Diesel $(30 \%)$

a Others $(4 \%)$

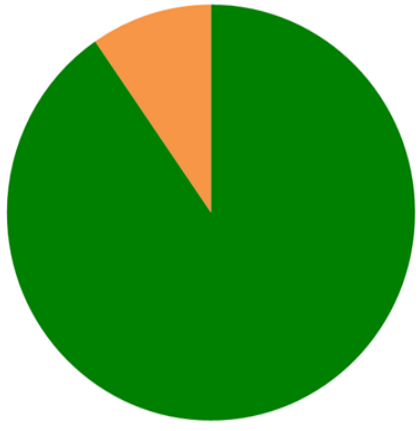

Nepal

(936 MW)

- Coal $(0 \%)$

- Gas $(0 \%)$

- Hydro (90\%)

- Nuclear $(0 \%)$

Diesel (10\%)

- Others $(0 \%)$

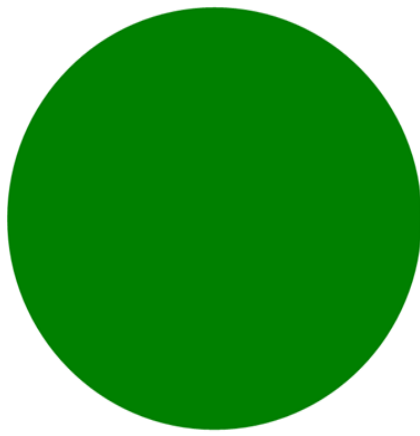

Bhutan

1,615 MW

- Coal $(0 \%)$

- Gas $(0 \%)$

- Hydro $(100 \%)$

- Nuclear $(0 \%)$

- Diesel $(0 \%)$

- Others $(0 \%)$

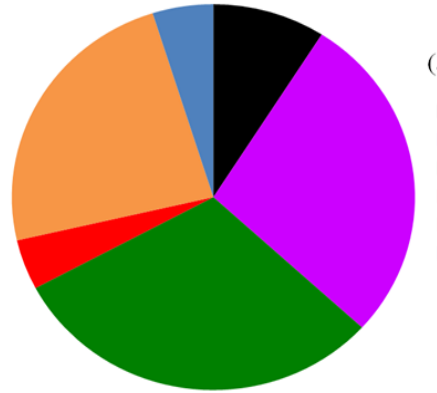

Pakistan

(33,401 MW)

- Coal $(9 \%)$

- Gas $(28 \%)$

- Hydro $(30 \%)$

- Nuclear $(4 \%)$

- Diesel $(24 \%)$

- Others $(5 \%)$

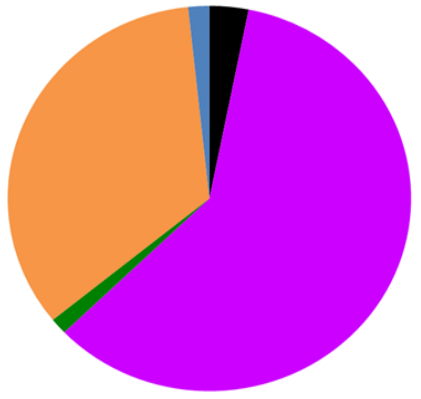

Bangladesh

(16,766 MW)

- Coal $(2.5 \%)$

- Gas $(60 \%)$

- Hydro $(1 \%)$

- Nuclear $(0 \%)$

- Diesel $(35 \%)$

Others $(1.5 \%)$

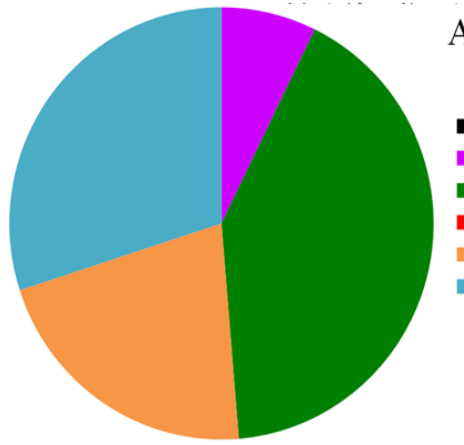

Afghanistan (690 MW)

- Coal $(0 \%)$

- Gas (7\%)

- Hydro $(42 \%)$

- Nuclear $(0 \%)$

- Diesel (21\%)

Others (30\%)

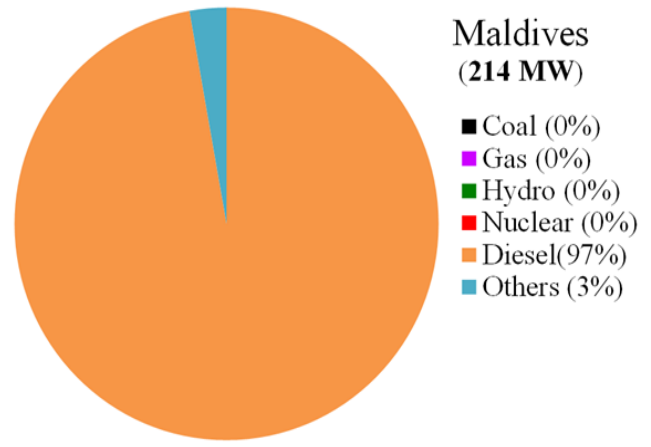

Figure 1: Present installed power generation capacity in South Asia, adapted from [1-9, 12-18]

Table 1: Installed \& forecasted capacity in South Asia, adapted from [20]

\begin{tabular}{|l|l|l|l|}
\hline Country & Installed Capacity (MW) & Forecasted Generation Capacity* (MW) & Current Grid Connected Peak Demand (MW) \\
\hline Afghanistan & 690 & 4790 & 5,000 \\
\hline Bangladesh & 16,766 & 24,000 & 11,637 \\
\hline Bhutan & 1,615 & 5,273 & 350 \\
\hline India & 344,003 & 515,000 & 164,000 \\
\hline Nepal & 936 & 4,000 & 1,200 \\
\hline Pakistan & 33,401 & 40,700 & 25,700 \\
\hline Sri Lanka & 4,055 & 19,370 & 2,523 \\
\hline Maldives & 240 & 365 & 284 \\
\hline
\end{tabular}

* All countries forecasted installed generation capacity in 2021 except Maldives which is in 2035 
connected power supply largely consists of imports from neighbouring Turkmenistan, Uzbekistan, Tajikistan and Iran, supplemented by domestic hydropower plants. Most hydropower plants have minimal reservoirs and are unable to provide storage beyond few hours. Peak flow for hydro is normally in the summer months, in contrast to peak customer demand in winter months. Domestic thermal plants make a small contribution to the total supply but are fueled by imported diesel and are extremely costly to operate. According to the World Bank Report 2018, Afghanistan imports over $80 \%$ of its grid connected power. In 2016, it imported 1,284 GWh from Uzbekistan, 1,184 GWh from Turkmenistan, $827 \mathrm{GWh}$ from Iran and $471 \mathrm{GWh}$ from Tajikistan. Its domestic grid connected generation was only $1,007 \mathrm{GWh}$ of which $96 \%$ was from hydro power plants $[1-3,8]$.

\subsection{Bangladesh (net importer)}

Current installed power generation capacity of Bangladesh is around 16,766 MW. Its peak demand for grid connected consumers is over $15 \%$ more than its highest generation (11,534 MW). Therefore, Bangladesh partially meets its power demand by importing $1,160 \mathrm{MW}$ power from India through two connections shown in Table 2. The unutilised installed technical capacity is 5,229 MW due to either fuel shortage; lack of local technical expertise, maintenance and repair and in some cases transmission and distribution constraints. Nearly $40 \%$ of current generation is undertaken by imported liquid fuel that generates $\mathrm{CO}_{2}$ similar to a coal fired power plant [7-12]. Bangladesh is currently negotiating with Nepal and Bhutan for joint investment in hydropower plants and import power from Bhutan and Nepal as well.

\subsection{India (net exporter)}

India is a net power exporter. It imports power from Bhutan but exports to Bangladesh, Nepal, and Myanmar
(Burma). According to a report compiled by the Central Electricity Authority of India (2017), India has become a net exporter of power from a net importer. During 201617 (April to February 2017), India exported 5,798 GWh to Nepal, Bangladesh and Myanmar while it imported 5,585 GWh from Bhutan. India exported $213 \mathrm{GWh}$ more than it imported. India has been marginally exporting power to Nepal in radial mode at $33 \mathrm{kV}$ and $132 \mathrm{kV}$ from Bihar and Uttar Pradesh. India imports power from Nepal as well. It currently exports around $235 \mathrm{MW}$ power through over 12 cross border interconnections at $11 \mathrm{kV}$, $33 \mathrm{kV}, 132 \mathrm{kV}$ and $400 \mathrm{kV}$ levels. Around $145 \mathrm{MW}$ alone is exported to Nepal with the commissioning of Muzaffarpur, Bihar, India - Dhalkhebar, Nepal $400 \mathrm{kV}$ interconnection since 2016. Another, $145 \mathrm{MW}$ export to Nepal is expected to begin through $132 \mathrm{kV}$ Katiya, Bihar - Kusaha, Nepal and 132 kV Raxaul, Bihar- Parwanipur, Nepal interconnections.

India exports 1,160 MW power to Bangladesh through two high voltage interconnections (1,000 MW through Baharampur, West Bengal, India and Bheramara, Bangladesh; and $160 \mathrm{MW}$ through Surjyamaninagar, Tripura, India and Comilla, Bangladesh).

\section{$1.4 \quad$ Nepal (net importer)}

Nepal is a net power importer. It has been importing 380 MW power from India due to high local demands and local power generation constraint. It has planned to import over 500 MW power from India in 2018-2020. Nepal faces power outages (load-shedding) of up to 16 hours a day during the dry season, when the available capacity of Nepal's hydropower decreases to a third of installed capacity. Peak load outstripped domestic power generation capacity, causing serious power shortage, which was partly met with by the import from India. Nepal also exports small quantity power to India during summer period. It has an ambitious target of reaching 16,500 MW

Table 2: Existing \& under-construction South Asia's cross-border interconnectors, adapted from [19]

\begin{tabular}{llll}
\hline Interconnectors & Description & Capacity (MW) & Estimated Cost (US\$ million) \\
\hline India-Bhutan (400 kV) & $\begin{array}{l}\text { Hydropower Export to India } \\
\text { Power Exchange between }\end{array}$ & 2100 & $140-160$ \\
India-Nepal (400 kV) & $\begin{array}{l}\text { India-Nepal } \\
\text { Power Exchange between } \\
\text { India-Bangladesh }\end{array}$ & $500-1000$ & 186 \\
India-Bangladesh (HDVC) & $\begin{array}{l}\text { Power Exchange between } \\
\text { India-Pakistan }\end{array}$ & $250-500$ & $50-150$ \\
India-Pakistan (220/400 kV & $\begin{array}{l}\text { Power Export to Sri Lanka (under } \\
\text { construction under-sea cable) }\end{array}$ & $500-1000$ & 650 \\
\hline India- Sri Lanka (HDVC) & &
\end{tabular}


Table 3: Average monthly power demand variation in South Asia, adapted from [21]

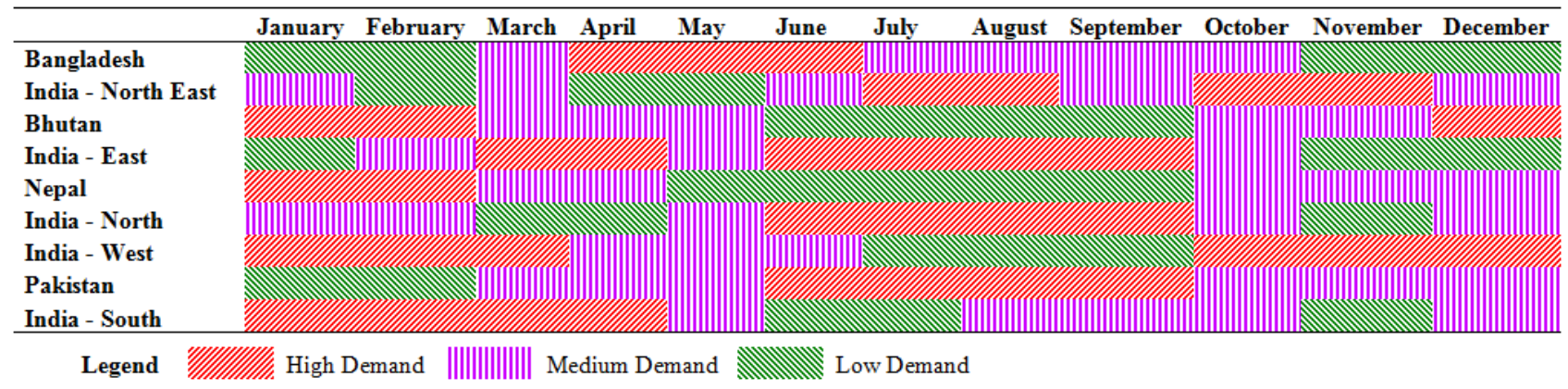

of hydro power installed capacity by 2030, which includes the joint project with India at Pancheshwar and China. Once all planned hydro power plants will be operational Nepal will emerge a regional power exporter [10-11]. Nepal also needs huge investment to minimise the environmental and social impacts caused by hydro dams.

\subsection{Pakistan (net importer)}

Pakistan currently imports just over $100 \mathrm{MW}$ power from Iran. It has planned to import $1,300 \mathrm{MW}$ power from Central Asia mainly Kyrgyzstan and Tajikistan in 2019 through a 1,200 km long cross border transmission line via Afghanistan under the Casa-1,000 power project. The power will be imported from the beginning of May to the end of September to reduce power deficit in summer when the demand is high. As per current plan, Afghanistan will tap 300 MW from Pakistan's 1,300 MW power from Central Asia. Pakistan is keen to develop relationship with the energy-rich central Asian states to overcome its power shortages. Pakistan also planned to import power from India subject to improved bilateral relation [1-3, 22].

\subsection{Bhutan (net exporter)}

Bhutan generates currently around 1,615 MW out of its economically feasible 26,760 MW. The peak power demand in Bhutan is only $350 \mathrm{MW}$. Most of its surplus power is exported to India. However, the domestic power demand is increasing annually around $17 \%$ due to increasing economic activities and small-scale industrialization [1-3, 13-15]. As power export constitutes Bhutan's $80 \%$ export earnings, the Bhutanese government is pursuing more hydropower development to earn more foreign exchange. Till now most medium and small-scale power plants are mainly 'Run-of-the-River' type. However, the large-scale power plants under construction and future power plants will be predominantly dam based. Hence significant financial commitments and plans would be required to minimise the environmental impact.

\subsection{Sri Lanka and Maldives}

Sri Lanka and Maldives are island nations. At this point of time, both countries power needs are met by their installed power generation capacities. Power generation by fuel type is shown in Figure 1. Currently both Sri Lanka and Maldives do not export or import from other South Asian nations.

\section{Discussion and Conclusion}

All South Asian nations except Maldives and Bhutan face power shortages. The average installed power generation capacity is $0.50 \mathrm{~kW}$ per person in South Asia. The demand for the grid-connected power is growing at around 10\% per annum, but the power supplies have not kept pace with the demand growth resulting in long outages and frequent unplanned interruptions. These uncertainties have imposed hardship on businesses that discourage business investment [1-3].

The installed power generation capacity varies from a low $0.03 \mathrm{~kW} /$ person in Nepal to a high $2.15 \mathrm{~kW} /$ person in Bhutan. Nepal faces load shedding over 16 hours a day during the dry season as its power generation capacity decreases to one-third of its installed capacity. Pakistan also experiences load shedding up to 8 to 10 hours a day during dry season. The shortage of power supply in India is over $5 \%[9,17]$. Bangladesh also faces load shedding hampering its industrial growth and lowering its annual GDP.

There are seasonal variations in generation and consumptions of power in South Asian nations. The seasonal complementarity of South Asian power systems is shown in Table 3. It is evident from the table that the peak power demand varies significantly across India, Pakistan, Bangladesh, Nepal and Bhutan in different months of the year. For example, Bangladesh has installed surplus power from November to February (4 months) in contrast to Bhutan and Nepal where these two countries face high demand for power. Therefore, Bangladesh can export power to Nepal and Bhutan during these four months. Both Nepal and Bhutan possess higher power 
generation capacity from May to September when Bangladesh and northern and north eastern India face huge power demand due to summer season. Bhutan and Nepal are in a position provide surplus power to Bangladesh and India during this time. Pakistan has surplus power general capacity in January-February whereas western and southern India faces higher power demand. Pakistan can export power to India during these two months. Similarly, India can export power to Pakistan during its peak demand in June-September (4 months). This cross-border power trade will enhance collective energy security and economic prosperity.

\section{Acknowledgments}

The authors like to express their sincere thanks to Dr Harun Chowdhury, School of Aerospace, Mechanical and Manufacturing Engineering, RMIT University, Melbourne, Australia for his assistance with the data collection.

\section{References}

[1] Alam, F., Alam, Q., Reza, S., Khurshid-ul-Alam, S.M., Saleque, K. and Chowdhury, H. (2017), A Review of Hydropower Projects in Nepal, Energy Procedia, Vol. 110: $581-585$

[2] Alam, F., Alam, Q., Reza, S., Khurshid-ul-Alam, S.M., Saleque, K. and Chowdhury, H. (2017), Sourcing Green Power in Bhutan: A Review, Energy Procedia, Vol. 110: 586-591

[3] Alam, F., Alam, Q., Reza, S., Alam, K., Saleque, S. and Ahsan, S. (2016), Liquefied Natural Gas (LNG) market and Australia, Proceedings of the 7th International Conference on Thermal Energy (ICTE2016), 22-24 December, Dhaka

[4] Khan, I., Alam, F. and Alam, Q. (2013), The global climate change and its effect on power generation in Bangladesh, Energy Policy, Vol. 61: 1460-1470

[5] Rasul, G. (2016), Managing the food, water, and energy nexus for achieving the Sustainable Development Goals in South Asia, Environmental Development, Vol. 18: 14-25

[6] Palit, D. and Bandyopadhyay, K.R. (2016), Rural electricity access in South Asia: Is grid extension the remedy? A critical review, Renewable and Sustainable Energy Reviews, Vol. 60: 1505-1515

[7] Alam, F., Alam, Q. and Sarkar, M.A. (2015), A Review of Power Sector by Energy Types in SAARC Countries, 2nd International Conference on Mechanical, Industrial and Materials Engineering (ICMIME2015), 11-13 December, Rajshahi, Bangladesh
[8] World Bank Report 2018), Afghanistan Renewable Energy Development-Issues and Options, pp. 1-107. Washington DC, USA

[9] Central Electricity Authority, Ministry of Power India, http://www.cea.nic.in/

[10] Sportlight Nepal, retrieved on 18 October 2018 from https://www.spotlightnepal.com/2017/08/10/nepal-importover-500-mw-electricity-india/

[11] Parikh, K. (2017), Powering India-Nepal ties, retrieved on from https://www.thehindu.com/opinion/lead/poweringindia-nepal-ties/article17960821.ece

[12] Bangladesh Power Development Board (BPDB), http://www.bpdb.gov.bd

[13] Bhutan Electricity Authority (BEA), Thimphu: http://www.bea.gov.bt/

[14] Druk Green Power Corporation Ltd: http://www.drukgreen.bt

[15] Bhutan Electricity Authority (BEA), Thimphu: http://www.bea.gov.bt/

[16] India Energy Security Scenarios 2047 (IESS 2047), NITI Aayog, Government of India, http://www.indiaenergy.gov.in/

[17] Ministry of Power, Government of India, New Delhi. http://powermin.nic.in/

[18] Nepal Electricity Company (NEC), Kathmandu, http://www.nea.org.np/

[19] Wijayatunga, P., Chattopadhyay, D. and Fernando, P. N. (2015), Cross-Border Power Trading in South Asia: A Techno Economic Rationale, ADB South Asia Working Paper Series No 38, August.

[20] SAARC Study (2017), SAARC Energy Centre, Islamabad, December, pp. 1-57

[21] Timilsina G.R. and Toman, M. (2016), Potential gains from expanding regional electricity trade in South Asia, Energy Economics, Vol. 60: 6-14

[22] The Daily News (2017), retrieved on 28 March, 2017 from https://www.thenews.com.pk/print/194831-Govtannounces-Pakistans-first-electricity-import-regulations 